\title{
Review \\ Application of Optimization and Modeling for the Enhancement of Composting Processes
}

\author{
Tea Sokač ${ }^{1}$, Davor Valinger ${ }^{2}$, Maja Benković ${ }^{2}$, Tamara Jurina ${ }^{2}{ }^{\mathbb{D}}$, Jasenka Gajdoš Kljusurić ${ }^{2}{ }^{\mathbb{D}}$, \\ Ivana Radojčić Redovniković ${ }^{1}$ and Ana Jurinjak Tušek ${ }^{2, *}$
}

1 Department of Biochemical Engineering, Faculty of Food Technology and Biotechnology, University of Zagreb, Pierottijeva 6, 10000 Zagreb, Croatia; tsokac@pbf.hr (T.S.); irredovnikovic@pbf.hr (I.R.R.)

2 Department of Process Engineering, Faculty of Food Technology and Biotechnology, University of Zagreb, Pierottijeva 6, 10000 Zagreb, Croatia; davor.valinger@pbf.unizg.hr (D.V.); maja.benkovic@pbf.unizg.hr (M.B.); tamara.jurina@pbf.unizg.hr (T.J.); jasenka.gajdos@pbf.unizg.hr (J.G.K.)

* Correspondence: ana.tusek.jurinjak@pbf.unizg.hr

check for updates

Citation: Sokač, T.; Valinger, D. Benković, M.; Jurina, T.; Gajdoš Kljusurić, J.; Radojčić Redovniković, I.; Jurinjak Tušek, A. Application of Optimization and Modeling for the Enhancement of Composting Processes. Processes 2022, 10, 229. https://doi.org/10.3390/pr10020229 Academic Editors: Philippe Bogaerts and Alain Vande Wouwer

Received: 30 December 2021

Accepted: 24 January 2022

Published: 25 January 2022

Publisher's Note: MDPI stays neutral with regard to jurisdictional claims in published maps and institutional affiliations.

Copyright: (C) 2022 by the authors. Licensee MDPI, Basel, Switzerland. This article is an open access article distributed under the terms and conditions of the Creative Commons Attribution (CC BY) license (https:// creativecommons.org/licenses/by/ $4.0 /)$.

\begin{abstract}
Composting is a more environmentally friendly and cost-effective alternative to digesting organic waste and turning it into organic fertilizer. It is a biological process in which polymeric waste materials contained in organic waste are biodegraded by fungi and bacteria. Temperature, $\mathrm{pH}$, moisture content, $\mathrm{C} / \mathrm{N}$ ratio, particle size, nutrient content and oxygen supply all have an impact on the efficiency of the composting process. To achieve optimal composting efficiency, all of these variables and their interactions must be considered. To this end, statistical optimization techniques and mathematical modeling approaches have been developed over the years. In this paper, an overview of optimization and mathematical modeling approaches in the field of composting processes is presented. The advantages and limitations of optimization and mathematical modeling for improving composting processes are also addressed.
\end{abstract}

Keywords: composting; optimization; mathematical modeling

\section{Introduction}

The steady growth of industrial production and trade in many countries of the world has led to a rapid increase in the generation of municipal and industrial waste in the last decade [1]. About 50\% of the waste generated worldwide consists of organic matter, generally from food, human and animal waste, garden and wood products [2]. A significant portion of this waste ends up in landfills and, if not properly treated, can pose a significant threat to the environment and human health [3]. The main producers are the agriculture and food sectors. Their waste can be used as a raw material to produce high value-added products, opening up a range of opportunities for sustainable production [4].

The treatment and disposal of waste is a very important and urgent issue, especially for local authorities who have to deal with this problem within their jurisdiction. Of course, many different strategies have been proposed to try to counteract and reduce waste production, such as composting [5] or anaerobic digestion. Anaerobic digestion has been suggested as an alternative method for high organic content waste. This method involves the degradation of organic matter without the presence of oxygen producing a potential energy source such as power generation or fuel gas [6]. Composting is an environmentally friendly and cost-effective substitute for processing organic waste and converting it into organic fertilizer. It is a biological process in which the polymeric waste materials contained in organic waste are degraded by the accelerated growth of fungi and bacteria [2,7]. In fact, it is a very complicated mechanism involving a variety of processes (microbiological, physicochemical and thermodynamic), all of which seem to be interrelated [8]. The products of the composting process are carbon dioxide and stable carbon forms that lead to the decomposition and mineralization of organic matter and the production of humic 
substances [7]. During the composting process, microorganisms release heat and energy as they decompose material. The heat generated increases the temperature of the compost pile, which ensures the inactivation of pathogenic microorganisms. For this reason, measuring the temperature of the pile is very important in evaluating the composting process [9]. The performance of the composting process is influenced by factors such as temperature, $\mathrm{pH}$, moisture content, $\mathrm{C} / \mathrm{N}$ ratio, particle size, nutrient content and oxygen supply $[7,10,11]$. The listed process variables can change frequently during the composting process. The largest and most significant temperature variation is observed during the thermophilic phase of the process. The changes in $\mathrm{pH}$ during composting are related to the proliferation of microorganisms. In addition, moisture content has a significant effect on the physical and chemical properties of the composting substrate. The $\mathrm{C} / \mathrm{N}$ ratio and aeration are also very important for the multiplication of microorganisms [10]. Thus, to achieve maximum efficiency in composting, all these factors and their interactions must be considered. To obtain a respectable and highly stabilized compost, the working conditions must be optimized, which is crucial for setting up processes and improving their efficiency. Optimization is very important to ensure good quality of the final product by performing the process under experimental conditions that are the most suitable for specific phenomena taking place during the composting. For example, the optimization of the compost maturity (expressed as $\mathrm{pH}$, or electrical conductivity, final $\mathrm{C} / \mathrm{N}$ ration, germination index or ash content) requires appropriate set-up design of $\mathrm{C} / \mathrm{N}$ ratio, moisture content, and aeration rate to ensure the conditions suitable for the microbial population growth which controls the organic matter degradation and, respectively, compost maturity [11,12]. Different optimization approaches have been described in the literature. For example, single-factor optimization has been used to determine the best process conditions $[13,14]$, but this approach is imprecise and may lead to misinterpretation of data; it also does not illustrate the interacting effects of variables and does not ensure the selection of optimal conditions. On the other hand, statistics-based experimental designs allows simultaneous analysis of all variables affecting the process as well as their interactions. This approach saves time and reduces errors in detecting the interaction of process parameters and has recently been published in the literature [15-20].

A poorly performed composting process results in an insufficiently stabilized organic matter or immature compost, which can affect the soil environment and plant growth, be a source of disease, and cause damage to crops through phytotoxicity [21]. The quality of compost is related to its stability and maturity. Stability is a term that refers to the resistance of a product's organic matter to extensive degradation or to greater microbiological activity, while maturity describes the ability of a product to be used effectively in agriculture and is related to plant growth and phytotoxicity aspects. Many physical, chemical and biological tests have been proposed to evaluate the stability and maturity of compost, but there is still no single accepted test to evaluate both parameters [22] that would provide the information necessary for process control.

Composting is a dynamic process characterized by a large number of interrelated effects. The main phases of composting are shown in a following graph (Figure 1). In the first phase (mesophilic phase), energy-rich, easily degradable compounds such as sugars and proteins are degraded by fungi, actinobacteria and bacteria. The increase in a temperature higher than $45^{\circ} \mathrm{C}$ leads to another composting phase called the thermophilic phase which is important because of the elimination of pathogens, parasites and ensures maximal sanitary conditions. The mesophilic microorganisms are replaced by thermophilic because they are adapted to higher temperatures and they are degrading more complex compounds. Compost temperature must not exceed $65^{\circ} \mathrm{C}$ as this would destroy almost all microorganisms and cause enzyme denaturation which can lead to the end of the composting process. When the activity of the thermophilic microorganisms decreases due to the exhaustion of the substrate, the temperature starts to decrease. That is the beginning of the second mesophilic phase which is characterized by an increasing number of organisms that degrade starch or cellulose. In the maturation phase, the compost pile is stabilized for plant use and the proportion of fungi increases, while bacterial numbers 
decline. Also, during the maturation phase are formed compounds that are not further degradable, such as lignin-humus complexes [12,23]. Bacteria, fungi, and actinomycetes degrade organic materials, resulting in compositional change and release of energy and water during the composting process.

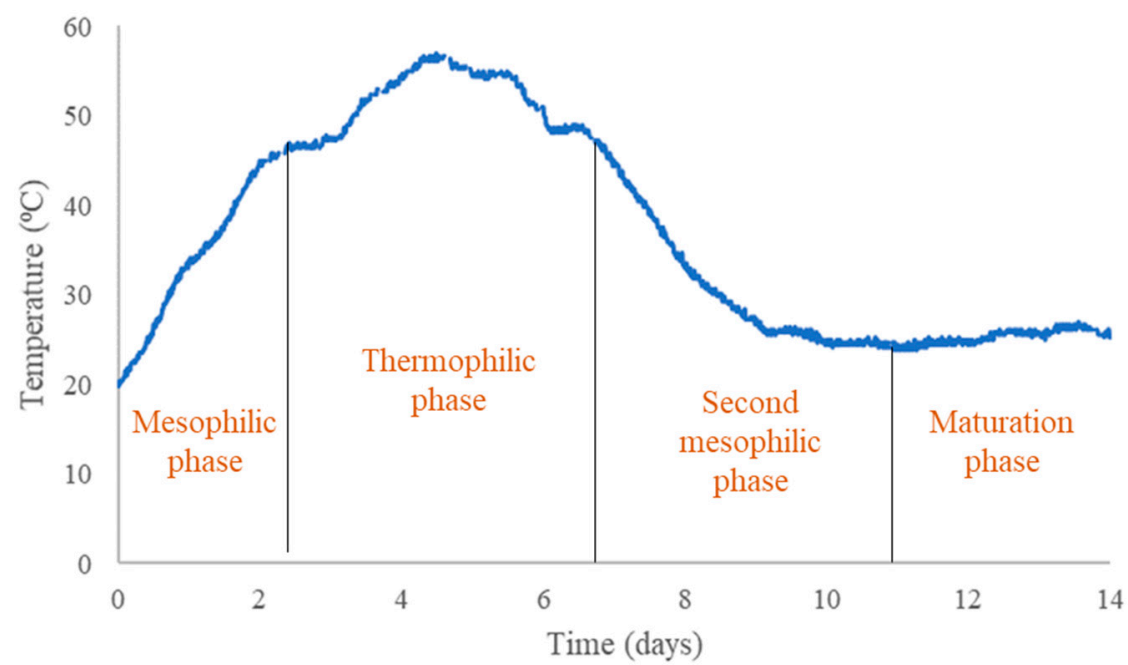

Figure 1. The main phases during the composting process (according to [24]).

As mentioned, composting is a highly complex process including numerous interconnected physical, chemical and biological phenomena. The particular connections are frequently non-linear and, therefore, numerous effects have to studied booth experimentally and theoretically. Therefore, mathematical modeling tools can be useful for interpretation of the complex dynamic interactions and for the development of the logical process design framework [25]. Mathematical models have been extensively used to gain valuable insights into the composting process [26-29]. Mathematical models of the composting process assist getting information on how different process variables and conditions like substrate composition, oxygen concentration, pollutants concentrations, composting duration, temperature and etc. effect the compost quality during the process [8]. Furthermore, as noted by Mason [30], mathematical models can reduce or even replace the need for experimental work when investigating novel processes. Considering the difficulties and costs associated with conducting laboratory and pilot experiments, it is desirable to improve the ability to study novel processes using models. To describe the composition process, the model must include the kinetics of the process as well as the mass and heat balances [2].

In this paper, an overview of optimization and mathematical modeling approaches in the field of composting processes is presented.

\section{Literature Search}

A comprehensive systematic review of the important scientific articles was conducted using the core collection in the Web of Science database for the period of the last 21 years (period from 2000 to 2021). The keywords "composting" and "optimization" and "composting" and "mathematical modeling" were used to search the title and abstract of the articles. Only indexed papers were selected for further analysis. For the field of optimization there were 77 articles, for the field of modeling a total of 222 articles.

\section{Optimization of Composting Process}

The estimation of optimal process parameters using practical and reliable models is still difficult and challenging and, therefore, multi-response optimization approaches have seen substantial growth and extension over the years [31]. According to Šibalija and Majstorović [32], optimization methods can be divided as follows: 
a. Conventional (statistical or mathematical based) method:

i. Iterative search techniques;

ii. Experimental design:

1. Method based on response surface methodology;

2. Methods based on factorial design;

3. Methods based on Taguchi design.

b. Non-conventional (artificial intelligence based) methods:

i. Method based on fuzzy logic;

ii. Methods based on artificial neural networks;

iii. Methods based on metaheuristic algorithms:

1. Genetic algorithm;

2. Simulated annealing;

3. Particle swarm optimization;

4. Ant colony optimization;

5. Tabu search;

6. Artificial bee colony algorithm;

7. Biogeography-based optimization;

8. Teaching-learning based optimization.

iv. Methods based on expert systems.

In the literature, there are several optimization strategies for the composting process. Statistical optimization methods based on design of experiments and artificial neural network modeling are the mostly used [11].

\subsection{Statistical Design of Experiments}

When designing or developing complex products or processes, multiple responses have to be considered simultaneously [33] and the term "optimization" in this context refers to increasing process productivity or improving product characteristics [34]. In order to achieve process optimization, detailed knowledge of process performance is required, which is why precise procedures are needed for experiments. The process of preparing and conducting an experiment so that appropriate data can be collected and analyzed using statistical methods to derive relevant conclusions from the experimental data while reducing the number of experiments is referred to as statistical design of experiments (DOE) [35]. Multivariate experimental design is an effective tool to improve the quality of information obtained from an investigation while reducing the number of experiments to be performed [36]. According to Said and Amin [36], process optimization using statistical design of experiments can be divided into three steps:

(i) experimental design;

(ii) model development to describe the experimental data using statistics and regression analysis; and

(iii) process optimization

DOE optimization efficiently explores the space of the system under study at different sample points, which reduces the computational cost and facilitates the analysis.

Design of experiments is an effective analytical method for modeling and analyzing the effects of control elements on performance outcomes. The typical experimental design is challenging, especially when you are working with a large number of trials and an increasing number of process variables. Selecting the most important process variables is the most important step in experimental design [37]. DOEs come in a variety of forms, including full factorial, fractional factorial, Placket-Burman, central composite design, Box-Behnken, Taguchi, and others [38]. The type of DOE is chosen based on the objectives of the experiments and the set of variables to be studied $[39,40]$. For example, the randomized complete block design (RCBD) approach is used to optimize only one fundamental element that is expected to be the most influential parameter for variation 
in a process [39,40]. A full factorial experimental design ensures that all factorial effects can be determined separately by conducting $2^{\mathrm{k}}$ trials ( $\mathrm{k}$ is the number of factors studied). However, it is not ideal in practice that the number of experiments required increases with increasing number of factors [41]. Full factorial experimental designs can be simplified by using fractional factorial experimental designs, where only the factor-specific effects are examined. An example of a fractional factorial design is $2^{(\mathrm{k}-\mathrm{p})}(\mathrm{p}$ is the proportion of the design to be created) [42]. There are two types of fractional factorial experimental designs: regular and non-regular. Regular fractional factorial designs are generated by detecting associations between variables, although non-regular fractional factorial designs, such as Placket-Burmann designs, are occasionally used in investigative studies because they have a small run [43]. Moreover, response surface designs are limited to eight variables and are only accessible to continuous factors, while the Taguchi robust experiment design is based on the fractional factorial design and includes orthogonal designs $[39,40]$. By definition, the Taguchi method is an experimental methodology that reduces the number of experiments by using orthogonal arrangements and limiting the influence of control variables. The Taguchi method is an approach that involves a plan of experiments with the aim of obtaining data in a controlled manner, performing these tests, and analyzing the data to gain knowledge about the behavior of the given process [37,44].

\subsection{Application of Optimization Methodology in Composting Processes}

The application of the optimization methodology in the composting process over the last 20 years is shown in Figure 2 and Table 1. It can be seen that the interest in this field has increased especially in the last 6 years probably due to growing interest in sustainable waste treatment

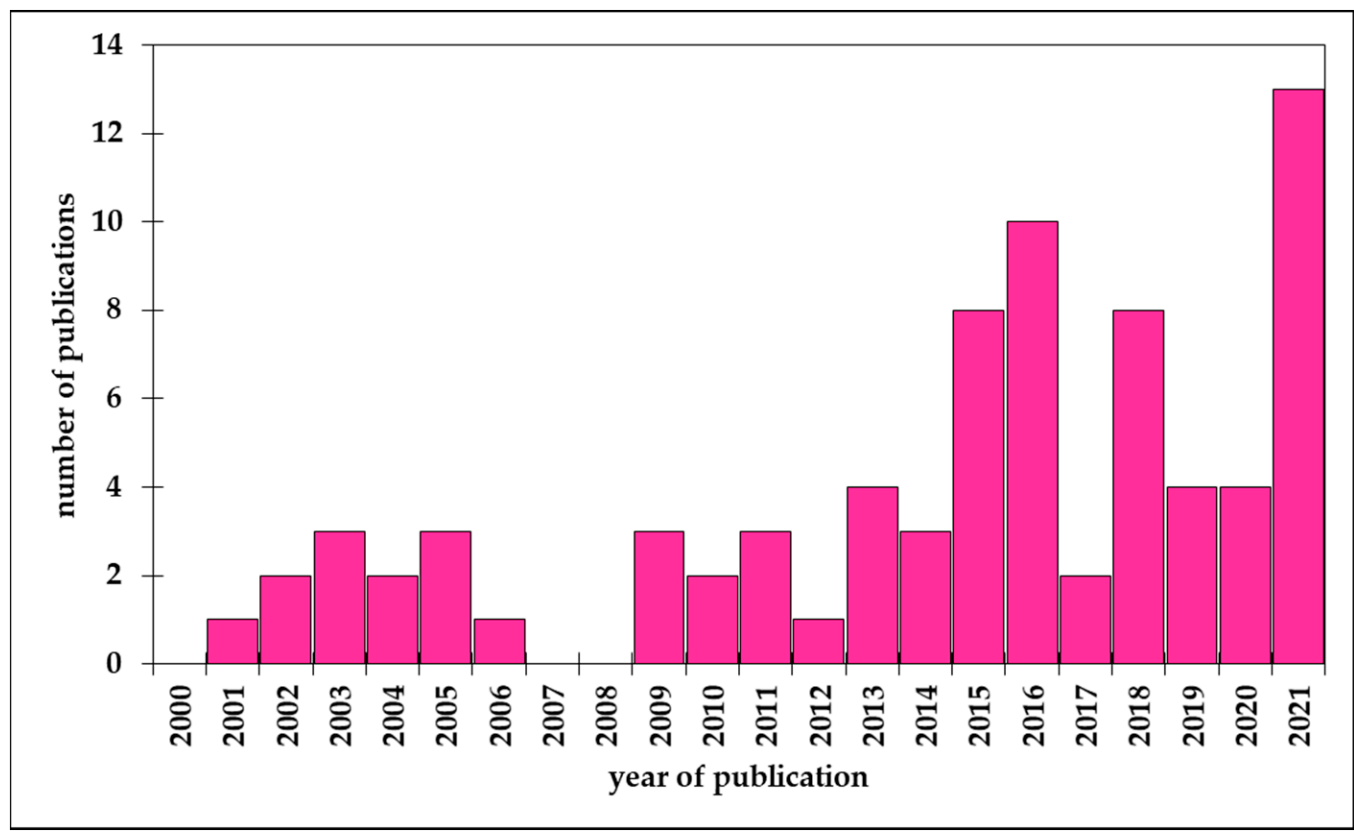

Figure 2. Number of publications on composting optimization in Web of Science database. 
Table 1. Examples of optimization of waste composting

\begin{tabular}{|c|c|c|c|c|}
\hline Composting Substrate & Process Variables & Optimization Method & Major Results & Reference \\
\hline Municipal solid waste & $\begin{array}{l}\text { Pollutant concentration (pyrene), } \\
\text { soil/compost mixing ratio, } \\
\text { compost stability expressed as } \\
\text { respiration index }\end{array}$ & $\begin{array}{l}\text { Response surface based on } \\
\text { central composite design (CCD) }\end{array}$ & $\begin{array}{l}\text { Experimental design ensures to obtain reliable values of optimal process } \\
\text { conditions for pyrene biodegradation. High values of coefficient of } \\
\text { correlations }\left(R^{2}>0.69\right) \text { confirmed that second-order model was suitable for } \\
\text { description of composting process. }\end{array}$ & {$[45]$} \\
\hline Municipal solid waste & $\begin{array}{l}\text { Temperature, moisture content, } \\
\text { oxygen flow rate, free air space }\end{array}$ & One-factor-at-a-time & $\begin{array}{l}\text { Optimisation of the process conditions based on data gathered in the } \\
\text { composting plant increases the performance of biological treatment plants } \\
\text { form } 53 \% \text { to } 107 \% \text {. }\end{array}$ & [46] \\
\hline Pulp and paper mill sludge & $\begin{array}{l}\text { Composting time, moisture, } \\
\text { addition of hazelnut kernels }\end{array}$ & $\begin{array}{l}\text { ANOVA test based on full } \\
\text { factorial experimental design }\end{array}$ & $\begin{array}{l}60 \% \text { removal of ammonium from compost can achieved by performing the } \\
\text { composting process under estimated optimal conditions ( } 5 \text { weeks, moisture } \\
\text { of } 50 \% \text { and addition of hazelnut kernel of } 25 \% \text { ). ANOVA showed that all } \\
\text { input variables have significant effect on the process output variable. }\end{array}$ & [48] \\
\hline $\begin{array}{l}\text { Cattle sultry and cattle manure } \\
\text { with maize/silage and } \\
\text { peach-juice pulp }\end{array}$ & $\begin{array}{c}\mathrm{pH}, \mathrm{C} / \mathrm{N} \text { ration and moisture } \\
\text { content }\end{array}$ & Factorial optimization & $\begin{array}{l}\text { Dewar autothermal assay was efficiently used to describe the relationship } \\
\text { between process input variables }\left(R^{2}=0.8\right) \text {. The developed model gives } \\
\text { information about the optimal composting conditions. }\end{array}$ & {$[50]$} \\
\hline $\begin{array}{l}\text { Medlar pruning waste with and } \\
\text { without cattle manure }\end{array}$ & Cattle manure addition & One-factor-at-a-time & $\begin{array}{l}\text { Results showed that addition of cattle manure increased electrical } \\
\text { conductivity, the total nitrogen content and organic-matter stability of the } \\
\text { compost. }\end{array}$ & {$[51]$} \\
\hline Kitchen waste & $\begin{array}{l}\text { Flay ash and bulking agent for } \\
\text { moisture optimization } \\
\text { Lime, temperature and } \\
\text { inoculum size for } \mathrm{C} / \mathrm{N} \\
\text { optimization }\end{array}$ & $\begin{array}{l}\text { Response surface methodology } \\
\text { based on Box-Benkhen design }\end{array}$ & $\begin{array}{l}\text { Interaction between bulking agent and fly ash was significant for the } \\
\text { compost moisture. Temperature, amount of lime addition and inoculum } \\
\text { size have positive effect on } \mathrm{C} / \mathrm{N} \text { ratio of the compost. Second order } \\
\text { polynomial equations described the experimental data with high precision; } \\
\text { for moisture content } R^{2}=0.9975 \text { and for } \mathrm{C} / \mathrm{N} \text { ratio } R^{2}=0.9947 \text {. }\end{array}$ & [15] \\
\hline
\end{tabular}


Table 1. Cont.

\begin{tabular}{|c|c|c|c|c|}
\hline Composting Substrate & Process Variables & Optimization Method & Major Results & Reference \\
\hline Municipal solid waste & $\begin{array}{l}\text { Pollutant concentration (pyrene), } \\
\text { soil/compost mixing ratio, } \\
\text { compost stability expressed as } \\
\text { respiration index }\end{array}$ & $\begin{array}{l}\text { Response surface based on } \\
\text { central composite design (CCD) }\end{array}$ & $\begin{array}{l}\text { Experimental design ensures to obtain reliable values of optimal process } \\
\text { conditions for pyrene biodegradation. High values of coefficient of } \\
\text { correlations }\left(R^{2}>0.69\right) \text { confirmed that second-order model was suitable for } \\
\text { description of composting process. }\end{array}$ & [45] \\
\hline $\begin{array}{l}\text { Paper mill sludge and corn } \\
\text { waste }\end{array}$ & $\begin{array}{l}\text { Materia type (corn cob and corn } \\
\text { husk), materia ratio, moisture, } \\
\text { and process duration }\end{array}$ & $\begin{array}{l}\text { Statistical optimization based on } \\
\text { full factorial design }\end{array}$ & $\begin{array}{l}\text { Additive dosage and composting duration had a positive effect on the } \\
\text { removal of ammonia during co-composting of pulp/paper mill sludge and } \\
\text { corn wastes. On the other hand, additive type and moisture content had } \\
\text { negative effects on the ammonia removal. } 91.84 \% \text { of ammonia was } \\
\text { removed when composting process was performed under optimal process } \\
\text { conditions. }\end{array}$ & [52] \\
\hline Biodegradable solid waste & $\begin{array}{l}\mathrm{pH} \text {, moisture content, } \\
\text { composting method }\end{array}$ & One-factor-at-a-time & $\begin{array}{l}\text { When the moisture level was kept at } 60 \% \text { and composting was done in } \\
\text { heaps and piles rather than pits and earthen pots, a long thermophilic } \\
\text { phase was evident. }\end{array}$ & [53] \\
\hline Food waste & $\begin{array}{l}\text { Natural zeoilte and biochar from } \\
\text { agricultural waste addition }\end{array}$ & One-factor-at-a-time & $\begin{array}{l}\text { Because of its strong affinity for cations, adding zeolites to composting } \\
\text { materials lowers the concentration of heavy metals in the final products. } \\
\text { The addition of biochar to the composting process increases nitrogen } \\
\text { retention. }\end{array}$ & [54] \\
\hline
\end{tabular}


The analysis of the optimization methods presented in Table 1 shows that different experimental designs (central composite experimental design, full factorial experimental design, Box-Behnken experimental design, etc.) have been used for the analysis of the composting process during the last 15 years. However, it should be emphasized that most of the optimization procedures presented were carried out using the one-factorat-a-time method. The one-factor-at-a-time method was used by Waqas et al. [54] and Chaher et al. [56] for the composting of food waste using in-vessel compost bioreactor by adding biochar prepared from lawn waste. The results showed that the addition of biochar improved the composting process and also the physiochemical properties of the final compost. The quality of the compost was evaluated using stabilization indicators such as moisture content, electrical conductivity, organic matter decomposition, change in total carbon and concentration of mineral nitrogen expressed as ammonium and nitrate. The same approach was described by Waqas et al. [57] for optimizing food waste composting by adding zeolites. The authors investigated the effects of natural zeolite and modified zeolite on the stability of compost produced in a bioreactor. Their results showed that modified zeolite significantly affected the compost properties (moisture content, electrical conductivity, organic matter, total carbon, mineral nitrogen, nitrification index, germination index). Bian et al. [58] also applied the one-factor-at-a-time method for agricultural waste composting with chicken manure, vegetable leaves and rice husks. The duration of thermal phase and conversion time on moisture, nutrients, carbon content and $\mathrm{C} / \mathrm{N}$ ratio of compost were analyzed by seven composting experiments in a batch composter. Zhang et al. [59] investigated the influence of turning frequency, straw and microbial inoculum on the efficiency of dairy manure composting in a field composting process. Data variance analysis (ANOVA) and non-parametric Spearman correlations were applied to analyze the effects of each process variable on compost temperature, water content, and $\mathrm{pH}$. Their results showed that to improve composting, the frequency of turning, the addition of straw and microbial inoculum at low temperatures $\left(\mathrm{T}<0{ }^{\circ} \mathrm{C}\right.$, winter period of composting) must be adjusted. The analyzed results showed that the ratio of dairy manure to straw 2:1 (v:v), 4 days of turning and the addition of $1.3 \mathrm{~L} / \mathrm{t}$ of inoculum were ideal for rapid heating and long duration of the thermophilic stage. The same approach, one-factor-at-a-time optimization, was used by Tabrika et al. [60] to optimize the composition of compost mixtures (tomato waste, olive pumice, sheep manure, chicken manure and sawdust). Their results indicate that the use of sheep manure and olive pumice improved the composting process of tomato waste. Lew et al. [61] optimized the temperature, moisture content, humidity and volume of liquid phase during composting of food waste in a smart bokashi composting system by also using a factor-by-time approach. Li et al. [62] estimated the optimal concentration of fulvic acid to improve the composting of straw and fungal residues based on the ANOVA analyzes of the experimental data, while Song et al. [63] used ANOVA analyses of the experimental data for optimization of the composting of food waste.

As described in the literature, statistical and mathematical optimization methods enable a statistically designed experiment that is cost-effective and allows analysis of the interactions between process variables. Sharma et al. [64] used a central composite design and response surface methodology to optimize floral waste composting. The floral wastes were composted using the stirred pile method with the addition of cow dung as inoculum origin and the stability and maturity of the compost was evaluated by $\mathrm{pH}$, total organic carbon, electrical conductivity, ammonium nitrogen. $\mathrm{C} / \mathrm{N}$ ratio, phosphorus, sodium, germination index, potassium and carbon dioxide production. The results obtained showed that second order polynomial equations can adequately describe the experimental data based on the input variables of the model (mass of floral waste and mass of cow dung). In the work of Calabi-Floody et al. [65], a three-level factorial design was used to evaluate the effects of three process variables (particle size, nitrogen addition, and Trichoderma harzianum inoculum concentration) on wheat straw composting. According to the results presented with the use of ANOVA, all three input variables and their interaction had a significant effect on the composting process. Multi-response optimization was used to investigate 
the effectiveness of the composting process to determine the technique most suitable to modify the wheat straw. It was found that the decrease in particle size has positive effect on the water holding capacity. Ajmal et al. [40] used Taguchi design method to optimize the temperature and time for composting process of agricultural wastes (poultry manure, vegetable wastes and rice straw) in vessels. They showed that performing the composting process under optimal conditions reduces the production of undesirable by-products. Moreover, Ajmal et al. [66] used Taguchi experimental design to optimize C/N ratio in agricultural waste composting based on composting temperature, composting time and initial inoculum amount in nine independent composting experiments.

Roman et al. [67] applied a Doehlert matrix experimental design (three variables at three levels) to evaluate the influence of hydrotreatment time, initial compost mass and hydrotreatment temperature on the municipal solid waste (MSW) composting process (total organic carbon, conductivity, liquid fraction volume and solid fraction carbon were the initial variables of the process) in 15 independent experiments simultaneously. From the experiments conducted, it was concluded that compost volume was the most important variable for the composting process. Gao et al. [19] applied simplex centroid design and response surface modeling followed by analysis of variance to optimize the composition of composting mixtures (pig manure, human feces, rice straw, and kitchen waste). In addition, Sokač et al. [24], presented the efficient use of the Box-Behnken experimental design (four variables at three levels) and response surface modelling (RSM) to optimize the composting process of biowaste in an adiabatic reactor with and without bioaugmentation. In addition to the optimization of the composting process, there are also examples of the application of the response surface methodology to optimize soil nutrient quality after compost addition (4-45\% of compost based on soil weight) [60] and the application of RSM and artificial neural network (ANN) modeling to optimize the adsorption efficiency of municipal solid waste compost for the removal of reactive dyes from aqueous mixtures [61]. The results presented by Mazumder et al. [68] showed that higher compost addition ( $>15 \%)$ increased the amount of nutrients in the soil over time, while Dehghani et al. [69] stated that both RSM modeling and ANN modeling have a significant ability to describe and optimize the adsorption mechanisms.

Considering that the relationships between variables affecting the composting process are mostly highly non-linear, it is necessary to use a non-linear modeling approach such as artificial neural networks. This methodology has been described by Soto-Paz et al. [70] for optimizing the composting of a mixture of biowaste and sugarcane filter cake. The effects of mixing ratio and rotation frequency were modeled using the ANN model and the optimal process settings were estimated using the particle swarm optimization algorithm. Aycan Duemenci et al. [20] modeled and optimized the composting of olive mill waste with the addition of five natural minerals using the ANN method with high precision. An efficient application of machine learning based optimization was also reported by Yamawaki et al. [71] for the degradation of bio-based plastics in the compost pile, where the developed models predicted with high accuracy the molecular weight of biopolymers based on the moisture content of compost, composting time, degree of crystallinity of biopolymers in the pretreatment phase, and nuclear magnetic resonance spectra of the solid phase of composting, and by Golbaz et al. [72] for the development of an optimal primary composite for composting based on the wet weight of the sludge cake, the concentration of volatile solids in the dry solids, the sludge density, the Kjeldahl nitrogen amount of the dry solids in the sludge cake, the Kjeldahl nitrogen amount of the material for mixture modification, the Kjeldahl nitrogen concentration of the filler component, and the Kjeldahl nitrogen concentration of the recycled components in the sludge as input variables of the model. Another example of the efficient use of ANN modeling to optimize the composting process was given by Dragoi et al. [73]. They presented a method for developing the ANN model for predicting the change in total concentration of petroleum hydrocarbons and organic carbon during the composting process of oily sludge. 
Taking into account listed results it can be noticed that there is potential of usage optimization methodology in the composting process. But there are still some limitations especially regarding to optimization based on design of experiments. According to Deaconu and Coleman [74] the major limitations of DOE are its degree of difficulty and number of experiments that must be undertaken to achieve statistical differences. Other issues include inability to manage specific variables (running the experiments with variables that will never yield an optimum value), difficulties recognizing all of the variables' impact on the process, and non-linearity between the variables which makes the interpretation of the interactions difficulty. So mentioned disadvantages tent to restrict how often DOE is employed in process optimization.

\section{Mathematical Modeling of Composting Process}

\subsection{Some Basic Principles of Composting Process Modeling}

Composting is a complicated bioprocess that involves several physical and biological processes. These interrelated and often highly non-linear processes produce a variety of phenomena that are difficult to study experimentally and analytically. Therefore, mathematical modeling can be useful for approximating the complex dynamic interplay that occurs during composting [75]. Mathematical modeling allows us to improve our knowledge of the process, reduce the time and energy required for experimental optimization, and enable computational simulations and development of process improvements [2]. According to Hangos and Cameron [76], mathematical models can be classified:

(i) based on variables properties as deterministic (model variables are well known) and stochastic (model variables are random);

(ii) based on deepened variable and their dependence on spatial position as lumped and distributed model;

(iii) based on mathematical description of the process as continuous and discrete;

(iv) based on mathematical structure as linear and non-linear.

Furthermore, due to their complexity mathematical model describing environmental process can be classified as:

(i) mechanistic (white box) models are developed when all required data about process mechanisms are gathered;

(ii) empirical (black box) models are developed when only experimental data are available and without understanding the mechanism in the process; and

(iii) combined (gray box) models [77].

Systematically, composting is a three-phase process: solid phase (solid composting substrate), liquid phase and gas (air) [40]. Thus, it is a great challenge to describe all the changes that take place in each phase and also between the different phases. As described in detail by Mason [30], mathematical models of the composting process usually include dynamic heat and mass balances and the microorganisms' growth. Growth of microorganisms during the composting process is usually described by first-order kinetics, Monod kinetics or empirical expressions developed for the specific set of experimental data. In addition to Mason [30], Li et al. [10] reviewed the key variables affecting the food waste composting process and modeling approaches for describing the phenomena occurring during composting. In addition, Walling et al. [2], Ajmal et al. [8] and Yang et al. [13] also reviewed the application of mathematical modeling in the composting process. Walling et al. [2] discussed in detail the current limitations of the developed mathematical model and which aspects should be further researched and developed. On the other hand, Ajmal et al. [8] reviewed with special emphasis on the models describing the heat exchange during the process and Yang et al. [13] with special emphasis on the changes of carbon, nitrogen, phosphorus and potassium during the composting process. 


\subsection{Application of Mathematical Modeling in Composting Process}

The growing interest in using of mathematical modeling in the field of composting is evident from the analysis of the data presented in Figure 3. It can be seen that the number of papers published using this method has increased steadily over the last 20 years. The increase in publications is mainly observed from 2016 to date.

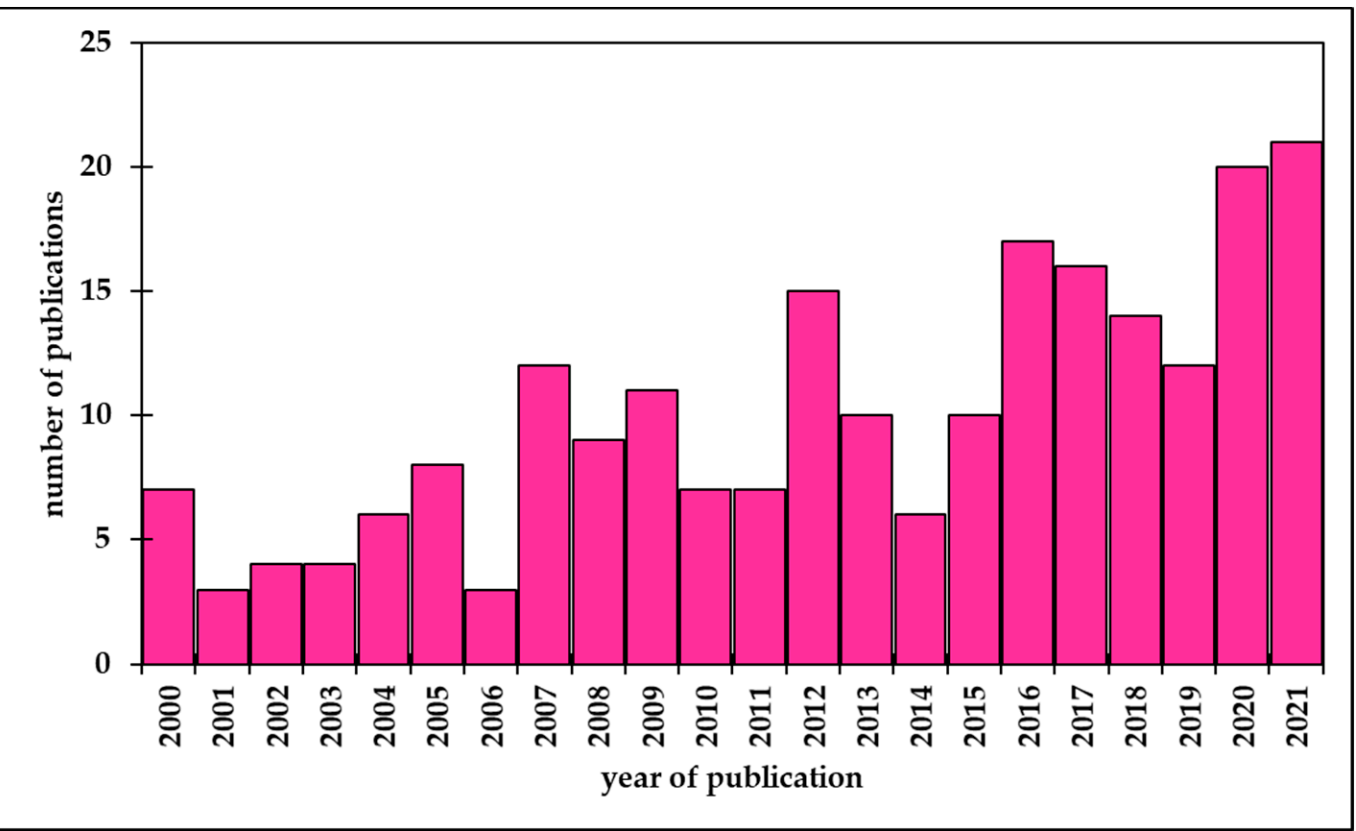

Figure 3. Number of publications on composting modeling in Web of Science.

Some specific characteristics and a brief description of some of the models used to describe the composting process from 2010 to 2021 can be found in Table 2. Based on the models presented, it can be seen that different modeling approaches have been used over the years.

There are examples of the use of simple empirical models [101], dynamic models [89-95] and artificial neural network models [88]. In general, simple empirical models are insufficient for simulating complex nonlinear dynamic processes. This is especially expressed when the analyzed process includes many performance modes with very different characteristics. Therefore, the fuzzy logic modeling approach was implemented to overcome the aforementioned limitations. As presented by Giusti and Marsili-Libelli [102], fuzzy logic modeling is very efficient for describing heat exchanges during the composting process. Moreover, Alavi et al. [103] applied kinetic modeling (first-order kinetic model was used for tetracycline degradation) and highly non-linear modeling with machine learning (artificial neural network modeling) to describe tetracycline elimination from chicken manure during co-composting with bagasse. The applicability of modeling from ANN was also confirmed by Roohi et al. [104] for planning phytoremediation of chromium- and zinc-contaminated soils by Bromus tomentellus with household waste compost and by Alavi et al. [105] for modeling the Elector-Fenton processing of compost leachate. 
Table 2. Examples of the application of the modeling for the composting processes.

Composting Substrate

Model Formulation

Partial differential equations for description of temperature and oxygen

concentration distribution within the composting pile at steady state. Energy balance

Industrial waste Mass balance for oxygen and heat balance

includes energy change due to air follow though composting pile, heat generated by

oxidation and heat generated by biological activity. Oxygen mass balance includes oxygen concentration change due to air follow though composting pile and due to oxidation.

Model describes the drainage of the waste water. In includes drainage from the composting pad area, direct precipitation falling and soil infiltration. Model uses weather data, data on vegetative filter strip buffer area data, soil infiltration rate, soil

Livestock manure

Hydrological mode

Vegetable waste

Mass balances for energy, oxygen, vapor and liquid water concentration

Bovine manure and sewage sludge

Organic $\mathrm{N}$ balance

Balances for substrate and oxygen concentration and energy transfer balance

Switchgrass and dog food mixture

Mathematical model of vertical moisture content movement

Fresh cow manure, organic faction of municipal solid waste, non-digested sludge from municipal wastewater treatment 
Table 2. Cont.

\section{Composting Substrate}

Green waste, biowaste and paper cardboard

Household waste

Energy transfer balance

Tobacco waste

Mass balance for substrate and biomass

Sewage sludge, straw and sawdust

Artificial neural network model

Sewage sludge, branches, grass clippings and ground leaves screening residues and sewage sludge

\section{Olive mill waste}

\section{Model Formulation}

Mass balances for organic matter change during composting
Mass balances for organic carbon and mass balances for organic pollutants

Mass balances for organic micro-pollutants dynamics during composting

Heat balance equation, water mass

balance, oxygen consumption and carbon dioxide production balances, compost volume change balance, biomass growt balance, nitrogen and phosphorous mass

(ec

Mathematical model in form of differential equations describes the dynamics of organic matter change during the composting. Organic matter was analysed in five fractions (easily degradable soluble, slowly degradable soluble, hemicelluloses, cellulose, and lignin fractions). Microbial population growth rate was described by Monod kinetics. Mathematical model in a form of differential equations and empirical algebraic equations describes the heat transfer during composting. Model includes heat production that is proportional to oxygen consumption rate and heat transfers by evaporation, convection between material and gas crossing the material, conduction and surface convection between gas and material in bottom and upper parts of the reactor,

Mathematical model in form of differential equations for description of biodegradation of organic matter from leachate which is produced during the composting process of tobacco waste. Applicability of Monod model, modified Monod model, Haldane model and expanded Haldane model for description of microbial growth was analysed.

Artificial neural network model for description of ammonia emission during composting based on selected input variables (sampling time, composting mixture temperature, composting mixture $\mathrm{pH}$, composting mixture conductivity, weight of dry mass in composting mixture, $\mathrm{C} / \mathrm{N}$ ratio of the composting mixture and ammonia nitrate content in composting mixture). Selected ANNs predicted the ammonia emission during composting with high precision $R^{2}>0.970$.

Mathematical model in a form of differential equations describes organic pollutants and organic carbon dynamics during composting. Model includes two modules that can be used separately or coupled. Microbial population growth rate was described by Monod kinetics.

First-order (using a single degradation coefficient) and dual first-order (using two separate degradation coefficients) kinetic models were used to describe the degradation of organic micro-pollutants (representing the most common groups of organic chemicals present in sewage sludge) during composting. Integrated model in a form of differential equations for decryption and prediction physicochemical and biological mechanism during composting. Insoluble organic matter hydrolysis was described using first-order kinetics. Microbial biomass growth was modelled with a double-substrate limitation (by hydrolyzed available organic substrate and oxygen) using Monod kinetics. The inhibitory factors of temperature and moisture content were included in the system.

\section{Reference} balances 
Table 2. Cont.

Composting Substrate

Heat balance equation, organic matter balance, inert substrate balance, oxygen

Sewage sludge and straw and carbon dioxide balances, water mass balance, biomass growt balance, ammonia mass balances

Heat balance, substrate mass balance,

Poultry manure and wheat straw oxygen mass balance, carbon dioxide mass balance, water mass balance

Pig manure, poultry manure, wheat straw Heat balance and oxygen mass balance

Heat balance, carbon dioxide mass

Animal manure balance, water mass balance and ammonia mass balances

Heat balance, mass balances for moisture content and total mass

Sewage sludge and wheat straw

Mass balances for: aerobic biomass, oxygen, soluble substrate, insoluble

Wood chips and dog food substrate, water, temperature and inert matter

Corn silage and cattle manure

Integrated model in a form of 11 differential equations for decryption of aerobic composting dynamics. Model describes the growth of mesophilic and thermophilic microorganisms by Contois kinetics equation. Model also refers to easily hydrolysable organic matter and inert organic matter of the used composting substrate. According to model changes of carbon dioxide concentrations and ammonia concentrations are inverse to changes in the oxygen concentration.

Integrated model composed of eight ordinary differential equations that take into account microbial kinetics, mass balance, heat balance and stoichiometry. The Monod

kinetic model described the microbial growth and its dependency on moisture content, oxygen and temperature.

Oxygen uptake rate model in form of differential equations. Model takes into account oxygen consumption diffusion form gas phase to solid phase and oxygen consumption. Model also includes microorganisms growth according to Monod model and substrate hydrolysis in anaerobic conditions.

Model for simulation of physicochemical and biological mechanism during composting in pile based on four modules; biodegradation, nitrogen transformation and volatilization, thermal exchanges and free air space evolution. Microbial growth was described by first order kinetic.

Integrated model for simulation of physicochemical and biological mechanism during composting. The model comprises first-order kinetics for organic matter (expressed as

volatile solid) degradation, energy balance equation with two-dimensional heat transfer; and mass balance equation with one-dimensional mass transfer. Organic matter degradation includes adjusted functions of temperature, oxygen, moisture content and free air space.

Integrated biomass-dependant dynamic model that takes into account temperature and biological growth under moisture, oxygen and substrate content. The aerobic biomass growth was described by the Monod model with dependence on oxygen concentration, soluble substrate concentration, moisture content and temperature. Model differs slowly and rapidly degradable substrates.

Heat balance included biological heat production, heating of reactor system, heat of input and output gas, conductive and convective heat losses through reactor wall and, latent heat of water evaporation. Substrate degradation was described by first-order kinetics. 
Table 2. Cont.

\section{Composting Substrate}

(1)

(n)

Sawdust, wheat-straw, chicken manure

Exponential equations describing decomposition rate

Mass balances for raw material,

Agricultural waste hemicellulose, lignin, soluble substrate, non-biodegradable volatile solids, and biomass

Organic fraction of municipal solid waste, organic fraction of municipal solid waste with orange peel waste, horticultural waste sewage sludge

\section{Model Formulation}

Non-linear exponential model

\section{Model Description}

Three kinetic models (first-order kinetics and exponential kinetics) were used to estimate the decomposition rate constant. Model 1 was a function of process temperatures, model 2 was a function of initial moisture content and the heat values, while model 3 was a function of process heat value and moisture content of the composting material.

Reference

Model splits raw composting material into certain type of substrates (hemicellulose, lignin, soluble substrate, non-biodegradable volatile solids) and biomass. Model also refers to three groups of microorganisms (soluble substrate degraders, hemicellulose degraders, and lignin degraders). Hemicellulose and lignin hydrolysis were modelled with Contois kinetics. Soluble substrate uptake was modelled by Tessier kinetics.

Model for description of cumulative oxygen demand and odour emission during composting. The odour emissions generated during the composting processes were fitted to proposed model with high accuracy $\left(R^{2}\right.$ within the range $\left.0.8-0.9\right)$. 
Analyzing the data in Table 2, it can also be noted that there are numerous research on the development of integrated models [89-93,96,98,100]. The integrated modeling approach aims to simultaneously describe and predict the physical, chemical and biochemical processes occurring during the composting process based on independent data sets. The described approach was also used by Vidriales-Escobar et al. [106] to model the composting mechanism in a tubular reactor. It is a two-phase model (gas phase for oxygen supply and solid phase containing the substrate for degradation) in the form of partial differential equations describing the temporal and spatial changes of selected variables. According to the authors, the presented model can represent with high precision the dynamic changes of temperature and oxygen in the gas phase, as well as the temporal changes of temperature, substrate and microbial biomass. Rentería-Tamayo et al. [107] also used a two-phase model for aerobic composting of sewage sludge, wood chips and grass in a tubular reactor. The aforementioned mathematical model described the growth of microorganisms (Contois kinetic model), substrate consumption, oxygen and heat exchange in terms of partial differential equations. Alternatively, Luangwilai et al. [108] proposed a one-dimensional model for the change in energy, oxygen, steam and liquid water during composting in the compost pile, while He et al. [26] used a three-dimensional approach to describe the temporal and spatial variations in temperature and oxygen concentrations during aerobic composting. The importance of oxygen concentration variation during aerobic composting of organic waste was also modeled by Martalo et al. [109]. Their model described the composting process in the biocell, which is a closed system with no interaction with the surrounding environment. The proposed model described aerobic degradation of dispersible substrate by aerobic bacteria, conversion of insoluble substrate to soluble and biomass degradation in terms of differential equations. Sokač et al. [24] described the adiabatic composting process of organic waste composting by a mass balance and by heat balance. Their results showed that the model used can describe the three temperature phases (mesophilic, thermophilic and cooling phase) of the composting process. As the number of model variables increases, the complexity of the model also increases. For the practical application of the model, it is certainly better to use the simplest possible model. Considering this fact, Walling and Vaneeckhaute [110], analyzed the applicability of six different modeling approaches to describe the composting process based only on the substrate decomposition rate without considering temperature, moisture and oxygen concentration.

Tsiodra et al. [111] created a dynamic model to describe the composting of olive mill waste with particular emphasis on the degradation of fats and oils and the influence of oxygen on process efficiency, while Sable et al. [112] modeled the degradation of polypropylene/polylactide/nanoclay blends/composite films in the co-composting of MSW and used first-order kinetics to describe polymer film degradation. In addition, Sable et al. [113] created a mathematical model to describe the biodegradation of acrylic acid-grafted polypropylene in the composting process using mass balances for carbon and carbon dioxide. The analyzed polymer degradation was described by the Komilis model with apartment lag phase with high accuracy. Ebrahimzadeh et al. [114] analyzed the kinetics of the kitchen waste composting mechanism. The experimental data on the change of volatile solids over time of the composting process were fitted to the zero-order kinetic model, first-order kinetic model, second-order kinetic model and nth-order kinetics. The results showed that the zero-order kinetics was the most suitable for describing the composting dynamics in a non-aerated reactor, while the nth-order kinetics was selected for describing the composting dynamics with aeration. Samaei et al. [115] constrain and discriminate hexadecane-degrading bacteria from compost produced from food waste, paper waste, garden waste, and organic material from municipal facilities. They modeled n-hexadecane degradation by zero-order kinetics, first-order kinetics, and first-order pseudokinetics.

On the other hand, Rafiee et al. [116] developed a mass balance model to describe the composting of organic waste (vegetable waste, fruit waste and food scraps). The developed model was successfully validated for predicting anaerobic digestion rate, methane oxidation and composting rate. In addition, Toledo et al. [117] used statistical modeling methods to 
predict odor emissions during composting of sewage sludge and olive leaves. The proposed model described the relationship between microbial growth and odor emission considering weather conditions (wind and temperature) at the composting pile. Ghinea et al. [118] also applied an efficient statistical regression method to build a model to describe food waste composting, while Soto-Paz et al. [119] applied integrated hierarchy-based modeling to select the optimal fillers and substances for process improvement. Wang et al. [120] created a three-phase nonlinear statistical model to analyze the thermal inactivation of pathogenic microorganisms in chicken litter compost, while Calisti et al. [121] used a linear programming algorithm to develop a new software tool for planning composting mixtures based on the physicochemical properties of the substrate (moisture, $\mathrm{C} / \mathrm{N}$ ratio, $\mathrm{C} / \mathrm{N}$ ratio availability, bulk density, and $\mathrm{pH}$ ) and raw material cost. In developing the new software tool, the authors assumed that all available raw materials would be used as much as possible and also proposed a successful minimization of the production cost of the composting mixture. Sobieraj et al. [122] created a model to predict carbon monoxide accumulation during composting of organic waste (dairy manure, grass clippings and pine sawdust) in a horizontal static bioreactor. The first-order kinetic model was used to describe carbon monoxide formation during the composting process. The effect of composting temperature on carbon monoxide production rate was modeled using a polynomial regression expression and a Gompertz exponential model. The obtained result allowed to adjust the air flow rate to the value required to keep the carbon monoxide concentration below the maximum recommended concentration $(<100 \mathrm{ppm})$. A very interesting approach to the analysis and monitoring of the composting process was presented by Wojcieszak et al. [123], where image analysis of compost samples was applied in conjunction with modeling ANN. The developed ANN models were able to determine the dry matter and dry organic matter of compost with high accuracy. The presented approach certainly has the potential for practical application, considering the reduction of analytical methods required for compost properties analysis. Based on the literature review presented, it can be concluded that mathematical modeling is of great importance for the composting process, but there are still some limitations. The most important one is the inability to develop generalize kinetic model of substrate biodegradation. For this reason, most of the developed models can only be used to describe the composting of the particular waste material. In addition, the complexity of the models also affects their applicability.

\section{Conclusions}

In this paper, an overview of optimization and modeling methods or approaches for the improvement of the composting process is presented. The operational performance of the composting process is determined by numerous variables such as temperature, $\mathrm{pH}$, moisture content, $\mathrm{C} / \mathrm{N}$ ratio, etc. To achieve optimal composting efficiency, all these variables and their relationships must be considered simultaneously. This can be achieved by using optimization and modeling tools, which ensure precise and controlled experimental design and data analysis, and allow the study of complex phenomena without extensive experimentation. From the results presented, it can be concluded that both optimization and mathematical modeling have significant potential to improve process conditions and intensify the composting process, respectively. Currently, many researchers are engaged in the development of integral models of the composting process, capable of describing and accurately predicting all physicochemical and biochemical changes that occur during composting. An acceptable model must provide a description of the multiphase process, but also be robust and applicable to different process conditions.

Author Contributions: Conceptualization, A.J.T.; methodology, D.V.; software, M.B.; writingoriginal draft preparation, T.S.; writing—review and editing, A.J.T.; visualization, T.J.; supervision, J.G.K.; project administration, I.R.R.; funding acquisition, I.R.R. All authors have read and agreed to the published version of the manuscript. 
Funding: The work was supported by the European Union through the European regional development fund, Competitiveness and Cohesion 2014-2020 (KK.01.1.1.07.0007).

Institutional Review Board Statement: Not applicable.

Informed Consent Statement: Not applicable.

Data Availability Statement: Not applicable.

Acknowledgments: The authors warmly acknowledge the supported by the European Union through the European regional development fund, Competitiveness and Cohesion 2014-2020 (KK.01.1. 1.07.0007).

Conflicts of Interest: The authors declare no conflict of interest.

\section{References}

1. Vaverková, M.D. Landfill impacts on the environment-Review. Geosciences 2019, 9, 431. [CrossRef]

2. Walling, E.; Trémier, A.; Vaneeckhaute, C. A review of mathematical models for composting. Waste Manag. 2020, $113,379-394$. [CrossRef] [PubMed]

3. Giron-Rojas, C.; Gil, E.; Garcia-Ruiz, A.; Iglesias, N.; Lopez, M. Assessment of biowaste composting process for industrial support tool development through macro data approach. Waste Manag. 2020, 105, 364-372. [CrossRef] [PubMed]

4. $\quad$ Freitas, L.C.; Barbosa, J.R.; Caldas da Costa, A.L.; Bezerra, F.W.F.; Pinto, R.H.H.; Junior, R.N.C. From waste to sustainable industry: How can agro-industrial wastes help in the development of new products? Resour. Conserv. Recyc. 2021, 169, 105466. [CrossRef]

5. Roy, D.; Azais, A.; Benkaraache, S.; Drogui, P.; Tyagi, R.D. Composting leachate: Characterization, treatment and future perspectives. Rev. Environ. Sci. Biotechnol. 2018, 17, 323-349. [CrossRef]

6. Yong, Z.; Dong, Y.; Zhang, X.; Tan, T. Anaerobic co-digestion of food waste and straw for biogas production. Renew Energy 2015, 78, 527-530. [CrossRef]

7. Barros, E.S.C.; Cavalcante de Amorim, M.C.; Olszevski, N.; Silva, P.T.S. Composting of winery waste and characteristics of the final compost according the Brazilian legislation. J. Environ. Sci. Health 2021, 56, 447-457. [CrossRef]

8. Ajmal, M.; Aiping, S.; Uddin, S.; Awaisa, M.; Faheem, M.; Ye, L.; Rehmans, K.; Ullah, M.S.; Shi, Y. A review on mathematical modelling of in-vessel composting process and energy balance. Biomass Convers Biorafin. 2020, 10, 1-13. [CrossRef]

9. Külcü, R.; Yaldiz, O. The composting of agricultural wastes and the new parameter for the assessment of the process. Ecol. Eng. 2014, 69, 220-225. [CrossRef]

10. Li, Z.; Lu, H.; Ren, L.; He, L. Experimental and modeling approaches for food waste composting: A review. Chemosphere 2013, 93, 1247-1257. [CrossRef] [PubMed]

11. Echarrafi, K.; El Harhouri, H.; Ben Abbou, M.; Rais, Z.; El Hassani, I.; El Haji, M. Mixture design formulation for optimized composting with the perspective of using artificial intelligence optimization algorithms. J. Appl. Sci. Environ. Stud. 2018, 1, 53-64.

12. Onwosi, O.C.; Igbokwe, V.C.; Odimba, J.N.; Eke, I.E.; Nwankwoala, M.O.; Iroh, I.N.; Ezeogu, I.E. Composting technology in waste stabilization: On the methods, challenges and future prospects. J. Environ. Manag. 2017, 190, 140-157. [CrossRef] [PubMed]

13. Yang, Z.; Muhayodin, F.; Larsen, O.C.; Miao, H.; Xue, B.; Rotter, V.S. A review of composting process models of organic solid waste with a focus on the fates of C, N, P, and K. Processes 2021, 9, 473. [CrossRef]

14. Shimizu, N. Process optimization of composting systems. Dairy Vet. Sci. J. 2018, 7, 555712. [CrossRef]

15. Iqbal, M.K.; Nadeem, A.; Sherazi, F.; Khan, R.A. Optimization of process parameters for kitchen waste composting by response surface methodology. Int. J. Environ. Sci. Technol. 2015, 12, 1759-1768. [CrossRef]

16. Hema Nalini, A.V.; Sreemahadevan Pillai, P.R.; Rao, Y.V.K.S. Optimization for temperature and time in co-composting municipal solid waste and brewery sludge. Int. J. Environ. Eng. Manag. 2016, 7, 1-23.

17. Asadu, C.O.; Egbuna, S.O.; Chime, T.O.; Eze, C.N.; Kevin, D.; Mbah, G.O.; Ezema, A.C. Survey on solid wastes management by composting: Optimization of key process parameters for biofertilizer synthesis from agro wastes using response surface methodology (RSM). Artif. Intell. Agric. 2019, 3, 52-61. [CrossRef]

18. Pottipati, S.; Kundu, A.; Kalamdhad, A.S. Process optimization by combining in-vessel composting and vermicomposting of vegetable waste. Bioresour. Technol. 2021, in press. [CrossRef]

19. Gao, Y.; Tan, L.; Liu, F.; Li, Q.; Wei, X.; Liu, L.; Li, H.; Zheng, X.; Xu, Y. Optimization of the proportion of multi-component rural solid wastes in mixed composting using a simplex centroid design. Bioresour. Technol. 2021, 341, 125746. [CrossRef]

20. Aycan Dümenci, N.; Cagcag Yolcu, O.; Aydin Temel, F.; Turan, N.G. Identifying the maturity of co-compost of olive mill waste and natural mineral materials: Modelling via ANN and multi-objective optimization. Bioresour. Technol. 2021, 338, 125516. [CrossRef]

21. Siles-Castellano, A.B.; López-González, J.A.; Jurado, M.M.; Estrella-González, M.J.; Suárez-Estrella, F.; López, M.J. Compost quality and sanitation on industrial scale composting of municipal solid waste and sewage sludge. Appl. Sci. 2021, 11, 7525. [CrossRef]

22. Oviedo-Ocana, E.R.; Torres-Lozada, P.; Marmlejo-Rebellona, L.F.; Hoyosa, L.V.; Gonzales, S.; Barrena, R.; Komilis, D.; Sanchez, A. Stability and maturity of biowaste composts derived by small municipalities: Correlation among physical, chemical and biological indices. Waste Manag. 2015, 44, 63-71. [CrossRef] [PubMed] 
23. Martinez, M.M.; Ortega Blu, R.; Janssens, M.; Fincheira, P. Grape pomace compost as a source of organic matter: Evolution of quality parameters to evaluate maturity and stability. J. Clean. Prod. 2019, 216, 56-63. [CrossRef]

24. Sokač, T.; Šalić, A.; Kučić Grgić, D.; Šabić Runjevac, M.; Vidaković, M.; Jurinjak Tušek, A.; Horvat, Đ.; Juras Krnjak, J.; Vuković Domonac, M.; Zelić, B. An enhanced composting process with bioaugmentation: Mathematical modelling and process optimization. Waste Manag. Res. 2021, 2021, 1-9. [CrossRef]

25. Papračnin, E.; Pertic, I. Mathematical modeling and simulation of the composting process in a pilot reactor. Glas. Hem. Tehnol. Bosne Herceg. 2017, 47, 39-48.

26. He, X.; Han, L.; Ge, J.; Huang, G. Modelling for reactor-style aerobic composting based on coupling theory of mass-heatmomentum transport and Contois equation. Bioresour. Technol. 2018, 253, 165-174. [CrossRef]

27. Koolivand, A.; Godini, K.; Saeedi, R.; Abtahi, H.; Ghamari, F. Oily sludge biodegradation using a new two-phase composting method: Kinetics studies and effect of aeration rate and mode. Process Biochem. 2019, 79, 127-134. [CrossRef]

28. Loan, L.T.T.; Takahashi, Y.; Nomura, H.; Yabe, M. Modeling home composting behavior toward sustainable municipal organic waste management at the source in developing countries. Resour. Conserv. Recycl. 2019, 140, 65-71. [CrossRef]

29. Jain, M.S.; Paul, S.; Kalamdhad, A.S. Kinetics and physics during composting of various organic wastes: Statistical approach to interpret compost application feasibility. J. Clean. Prod. 2020, 255, 120324. [CrossRef]

30. Mason, I.G. Mathematical modelling of the composting process: A review. Waste Manag. 2006, 26, 3-21. [CrossRef]

31. Rothlauf, F. Optimization Methods. In Design of Modern Heuristics; Springer: Berlin/Heidelberg, Germany, $2011 ;$ pp. 45-102. [CrossRef]

32. Šibalija, T.V.; Majstorović, V.D. Optimisation methods. In Advanced Multiresponse Process Optimization; Springer: Berlin/Heidelberg, Germany, 2016; pp. 21-63. [CrossRef]

33. Tsai, C.W.; Tong, L.I.; Wang, C.H. Optimization of multiple responses using data envelopment analysis and response surface methodology. J. Appl. Sci. Eng. 2010, 13, 197-203.

34. Vera Candioti, L.; De Zan, M.M.; Cámara, M.S.; Goicoechea, H.C. Experimental design and multiple response optimization. Using the desirability function in analytical methods development. Talanta 2014, 124, 123-138. [CrossRef] [PubMed]

35. Uy, M.; Telford, J.K. Optimization by design of experiment techniques. In Proceedings of the 2009 IEEE Aerospace Conference, Big Sky, MT, USA, 7-14 March 2009; pp. 1-10. Available online: https:/ / ieeexplore.ieee.org/document/4839625 (accessed on 23 July 2021).

36. Said, K.A.M.; Amin, M.A.M. Overview on the response surface methodology (RSM) in extraction processes. JASPE 2015, 2, 8-17.

37. Pang, J.S.; Ansari, M.N.M.; Zaroog, O.S.; Ali, M.H.; Sapuan, S.M. Taguchi design optimization of machining parameters on the $\mathrm{CNC}$ end milling process of halloysite nanotube with aluminium reinforced epoxy matrix (HNT/Al/Ep) hybrid composite. HBRC J. 2014, 10, 138-144. [CrossRef]

38. Saleem, M.M.; Somá, A. Design of experiments based factorial design and response surface methodology for MEMS optimization. Microsyst. Technol. 2015, 21, 263-276. [CrossRef]

39. Raykundaliya, D.; Shanubhogue, A. Comparison study: Taguchi methodology vis.-a-vis. response surface methodology through a case study of accelerated failure in spin-on-filter. Int. Adv. Res. J. Sci. Eng. Technol. 2015, 2, 1-5.

40. Ajmal, M.; Aiping, S.; Awais, M.; Ullah, M.S.; Saeed, R.; Uddin, S.; Ahmad, I.; Zhou, B.; Zihao, X. Optimization of pilot-scale in-vessel composting process for various agricultural wastes on elevated temperature by using Taguchi technique and compost quality assessment. Process Saf. Environ. Prot. 2020, 140, 34-45. [CrossRef]

41. Gunst, R.F.; Mason, R.L. Fractional factorial design. Rev. Compt. Stat. 2009, 1, 234-244. [CrossRef]

42. Rezende, C.A.; Atta, B.W.; Breitkreitz, M.C.; Simister, R.; Gomez, L.D.; McQueen-Mason, S.J. Optimization of biomass pretreatments using fractional factorial experimental design. Biotechnol. Biofuels. 2018, 11, 206. [CrossRef]

43. Phoa, F.K.H.; Xu, H.; Wong, W.K. The use of nonregular fractional factorial designs in combination toxicity studies. Food Chem. Toxicol. 2019, 47, 2183-2188. [CrossRef]

44. Aslitürk, I.; Akkus, H. Determining the effect of cutting parameters on surface roughness in hard turning using the Taguchi method. Measurement 2011, 44, 1697-1704. [CrossRef]

45. Sayara, T.; Sarra, M.; Sánchez, A. Optimization and enhancement of soil bioremediation by composting using the experimental design technique. Biodegradation 2010, 21, 345-356. [CrossRef] [PubMed]

46. Baptista, M.; Antunes, F.; Silveira, A. Diagnosis and optimization of the composting process in full-scale mechanical-biological treatment plants. Waste Manag. Res. 2011, 29, 565-573. [CrossRef] [PubMed]

47. Cabeza, I.O.; López, R.; Ruiz-Montoya, M.; Díaz, M.J. Maximising municipal solid waste—Legume trimming residue mixture degradation in composting by control parameters optimization. J. Environ. Manag. 2013, 128, 266-273. [CrossRef] [PubMed]

48. Aycan, N.; Turan, N.G.; Orgonenel, O. Optimization of process parameters for composting of pulp/paper mill sludge with hazelnut kernel using a statistical method. Environ. Prot. Eng. 2014, 40, 127-138. [CrossRef]

49. Mohammad, N.; Alam, M.Z.; Kabashi, N.A. Optimization of effective composting process of oil palm industrial waste by lignocellulolytic fungi. J. Mater. Cycles Waste Manag. 2015, 17, 91-98. [CrossRef]

50. Torres-Climent, A.; Martin-Mata, J.; Marhuenda-Egea, F.; Moral, R.; Barber, X.; Perez-Murcia, M.D.; Paredes, C. Composting of the solid phase of digestate from biogas production: Optimization of the moisture, $\mathrm{C} / \mathrm{N}$ ratio, and $\mathrm{pH}$ conditions. Commun. Soil Sci. Plant Anal. 2015, 46, 197-207. [CrossRef] 
51. Parades, C.; Moreno-Caselles, J.; Agullo, F.; Andreu-Rodriguez, J.; Torres Climent, A.; Bustamante, M.A. Optimization of medlar pruning waste composting process by cattle manure addition. Commun. Soil Sci. Plant Anal. 2015, 6, 228-237. [CrossRef]

52. Aycan, N.; Turan, N.G. Statistical optimization to model ammonia removal during co-composting of pulp/paper mill sludge and corn wastes. Clean Soil Air Water 2016, 44, 1572-1577. [CrossRef]

53. Sarkar, S.; Pal, S.; Chanda, S. Optimization of a vegetable waste composting process with a significant thermophilic phase. Procedia Environ. Sci. 2016, 35, 435-440. [CrossRef]

54. Waqas, M.; Nizami, A.S.; Aburiazaiza, A.S.; Barakat, M.A.; Rashid, I.M.; Ismail, I.M.I. Optimizing the process of food waste compost and valorizing its applications: A case study of Saudi Arabia. J. Clean. Prod. 2017, 176, 426-438. [CrossRef]

55. Varma, V.S.; Kalamdhad, A.S.; Kumar, B. Optimization of waste combinations during in-vessel composting of agricultural waste. Waste Manag. Res. 2017, 35, 101-109. [CrossRef] [PubMed]

56. Chaher, N.H.; Chakchouk, M.; Engler, N.; Nassour, A.; Nelles, M.; Hamdi, M. Optimization of food waste and biochar in-vessel co-composting. Sustainability 2020, 12, 1356. [CrossRef]

57. Waqas, M.; Nizami, A.S.; Aburiazaiza, A.S.; Barakat, M.A.; Asam, Z.Z.; Khattak, B.; Rashid, M.I. Untapped potential of zeolites in optimization of food waste composting. J. Environ. Manag. 2019, 241, 99-112. [CrossRef] [PubMed]

58. Bian, B.; Hu, X.; Zhang, S.; Lv, C.; Yang, Z.; Yang, W.; Zhang, L. Pilot-scale composting of typical multiple agricultural wastes: Parameter optimization and mechanisms. Bioresour. Technol. 2019, 28, 121482. [CrossRef] [PubMed]

59. Zhang, Q.; Liu, J.; Guo, H.; Li, E.; Yan, Y. Characteristics and optimization of dairy manure composting for reuse as a dairy mattress in areas with large temperature differences. J. Clean. Product. 2019, 232, 1053-1061. [CrossRef]

60. Tabrika, I.; Mayad, E.H.; Furze, J.N.; Zaafrani, M.; Azim, K. Optimization of tomato waste composting with integration of organic feedstock. Environ. Sci. Pollut. Res. Int. 2021, 28, 64140-64149. [CrossRef]

61. Lew, P.S.; Nik Ibrahim, N.N.L.; Kamarudin, S.; Thamrin, N.M.; Misnan, M.F. Optimization of bokashi-composting process using effective microorganisms-1 in smart composting bin. Sensors 2021, 21, 2847. [CrossRef]

62. Li, F.; Yu, H.; Li, Y.; Wang, Y.; Shen Resource, J.; Hu, D.; Han, Y. The quality of compost was improved by low concentrations of fulvic acid owing to its optimization of the exceptional microbial structure. Bioresour. Technol. 2021, 342, 125843. [CrossRef]

63. Song, B.; Manu, M.K.; Li, D.; Wang, C.; Varjani, S.; Ladumor, N.; Wong, J.W.C. Food waste digestate composting: Feedstock optimization with sawdust and mature compost. Bioresour. Technol. 2021, 341, 125759. [CrossRef]

64. Sharma, D.; Yadav, K.D.; Kumar, S. Biotransformation of flower waste composting: Optimization of waste combinations using Response Surface Methodology. Bioresour. Technol. 2018, 270, 198-207. [CrossRef] [PubMed]

65. Calabi-Floody, M.; Medina, J.; Suazo, J.; Ordiqueo, M.; Aponte, H.; Mora, M.; Rumpel, C. Optimization of wheat straw cocomposting for carrier material development. Waste Manag. 2019, 98, 37-49. [CrossRef] [PubMed]

66. Ajmal, M.; Shi, A.; Awais, M.; Mengqi, Z.; Zihao, X.; Shabbir, A.; Ye, L. Ultra-high temperature aerobic fermentation pretreatment composting: Parameters optimization, mechanisms and compost quality assessment. J. Environ. Chem. Eng. 2021, 9, 105453. [CrossRef]

67. Roman, F.F.; de Tuesta, J.L.D.; Praca, P.; Silva, A.M.T.; Faria, J.L.; Gomes, H.T. Hydrochars from compost derived from municipal solid waste: Production process optimization and catalytic applications. J. Environ. Chem. Eng. 2021, 9, 104888. [CrossRef]

68. Mazumder, P.; Akhil, P.M.; Khwairakpam, M.; Mishra, U.; Kalamdhad, A.S. Enhancement of soil physico-chemical properties post compost application: Optimization using Response Surface Methodology comprehending Central Composite Design. J. Environ. Manag. 2021, 289, 112461. [CrossRef]

69. Dehghani, M.H.; Salari, M.; Karri, R.R.; Hamidi, F.; Bahadori, R. Process modeling of municipal solid waste compost ash for reactive red 198 dye adsorption from wastewater using data driven approaches. Sci. Rep. 2021, 11, 11613. [CrossRef] [PubMed]

70. Soto-Paz, J.; Alfonso-Morales, W.; Caicedo-Bravo, E.; Oviedo-Ocaña, E.R.; Torres-Lozada, P.; Manyoma, P.C.; Sanchez, A.; Komilis, D. A new approach for the optimization of biowaste composting using artificial neural networks and particle swarm optimization. Waste Biomass Valori. 2019, 11, 3937-3951. [CrossRef]

71. Yamawaki, R.; Tei, A.; Ito, K.; Kikuchi, J. Decomposition factor analysis based on virtual experiments throughout Bayesian optimization for compost-degradable polymers. Appl. Sci. 2021, 11, 2820. [CrossRef]

72. Golbaz, S.; Zamanzadeh, M.Z.; Pasalari, H.; Farzadkia, M. Assessment of co-composting of sewage sludge, woodchips, and sawdust: Feedstock quality and design and compilation of computational model. Environ. Sci. Pollut. Res. Int. 2021, 28, 12414-12427. [CrossRef]

73. Dragoi, E.-N.; Godini, K.; Koolivand, A. Modeling of oily sludge composting process by using artificial neural networks and differential evolution: Prediction of removal of petroleum hydrocarbons and organic carbon. Environ. Technol. Innov. 2021, 21, 101338. [CrossRef]

74. Deaconu, S.; Coleman, H.W. Limitations of statistical design of experiments approaches in engineering testing. J. Fluid. Eng. 2000, 122, 254. [CrossRef]

75. Petrić, I.; Selimbašić, V. Development and validation of mathematical model for aerobic composting process. Chem. Eng. J. 2008, 139, 304-317. [CrossRef]

76. Hangos, K.; Cameron, I. Process Modeling and Model Analysis; Academic Press: Cambridge, MA, USA, $2001 ;$ pp. 1-33.

77. Šalić, A.; Jurinjak Tušek, A.; Zelić, B. Modeling of environmental processes. In Environmental Engineering; Springer: Berlin/Heidelberg, Germany, 2018; pp. 317-356. 
78. Luangwilai, T.; Sidhu, H.S.; Nelson, M.I.; Chen, X.D. Modelling air flow and ambient temperature effects on the biological self-heating of compost piles. Asia-Pac. J. Chem. Eng. 2010, 5, 609-618. [CrossRef]

79. Webber, D.F.; Mickelson, S.K.; Wulf, L.W.; Richard, T.L.; Ahn, H.K. Hydrologic modeling of runoff from a livestock manure windrow composting site with a fly ash pad surface and vegetative filter strip buffers. J. Soil Water Conserv. 2010, 65, 252-260. [CrossRef]

80. Luangwilai, T.; Sidhu, H.S.; Nelson, M.I. A two dimensional reaction-diffusion model of compost piles. Anziam J. 2010, 53, 34-52. [CrossRef]

81. Gil, M.V.; Carballo, M.T.; Calvo, L.F. Modelling N mineralization from bovine manure and sewage sludge composts. Bioresour. Technol. 2011, 102, 863-871. [CrossRef] [PubMed]

82. Fontenelle, L.T.; Corgié, S.C.; Walker, L.P. Integrating mixed microbial population dynamics into modeling energy transport during the initial stages of the aerobic composting of a switchgrass mixture. Bioresour. Technol. 2011, 102, 5162-5168. [CrossRef] [PubMed]

83. Seng, B.; Kaneko, H.; Hirayama, K.; Katayama-Hirayama, K. Development of water movement model as a module of moisture content simulation in static pile composting. Environ. Technol. 2012, 33, 1685-1694. [CrossRef]

84. Illa, J.; Prenafeta-Boldú, F.X.; Bonmatí, A.; Flotats, X. Empirical characterisation and mathematical modelling of settlement in composting batch reactors. Bioresour. Technol. 2012, 104, 451-458. [CrossRef]

85. Zhang, Y.; Lashermes, G.; Houot, S.; Doublet, J.; Steyer, J.P.; Zhu, Y.G.; Barriuso, E.; Garnier, P. Modelling of organic matter dynamics during the composting process. Waste Manag. 2012, 32, 9-30. [CrossRef]

86. de Guardia, A.; Petiot, C.; Benoist, J.C.; Druilhe, C. Characterization and modelling of the heat transfers in a pilot-scale reactor during composting under forced aeration. Waste Manag. 2012, 32, 1091-1105. [CrossRef] [PubMed]

87. Ćosić, I.; Vuković, M.; Gomzi, Z.; Briški, F. Comparison of various kinetic models for batch biodegradation of leachate from tobacco waste composting. Rev. Chim. 2012, 63, 967-971.

88. Boniecki, P.; Dach, J.; Pilarski, K.; Piekarska-Boniecka, H. Artificial neural networks for modeling ammonia emissions released from sewage sludge composting. Atmos. Environ. 2012, 57, 49-54. [CrossRef]

89. Lashermes, G.; Zhang, Y.; Houot, S.; Steyer, J.P.; Patureau, D.; Barriuso, E.; Garnier, P. Simulation of organic matter and pollutant evolution during composting: The COP-compost model. J. Environ. Qual. 2013, 42, 361-372. [CrossRef]

90. Sadef, Y.; Poulsen, T.G.; Bester, K. Modeling organic micro pollutant degradation kinetics during sewage sludge composting. Waste Manag. 2014, 34, 2007-2013. [CrossRef]

91. Vasiliadou, I.A.; Chowdhury, A.K.M.M.B.; Akratos, C.S.; Tekerlekopoulou, A.G.; Pavlou, S.; Vayenas, D.V. Mathematical modeling of olive mill waste composting process. Waste Manag. 2015, 43, 61-71. [CrossRef]

92. Białobrzewski, I.; Mikš-Krajnik, M.; Dach, J.; Markowski, M.; Czekała, W.; Głuchowska, K. Model of the sewage sludge-straw composting process integrating different heat generation capacities of mesophilic and thermophilic microorganisms. Waste Manag. 2015, 43, 72-83. [CrossRef]

93. Petric, I.; Mustafić, N. Dynamic modeling the composting process of the mixture of poultry manure and wheat straw. J. Environ. Manag. 2015, 161, 392-401. [CrossRef]

94. Ge, J.; Huang, G.; Huang, J.; Zeng, J.; Han, L. Modeling of oxygen uptake rate evolution in pig manure-wheat straw aerobic composting process. Chem. Eng. J. 2015, 276, 29-36. [CrossRef]

95. Oudart, D.; Robin, P.; Paillat, J.M.; Paul, E. Modelling nitrogen and carbon interactions in composting of animal manure in naturally aerated piles. Waste Manag. 2015, 46, 588-598. [CrossRef]

96. Zhang, J.; Chen, T.-B.; Gao, D. Simulation of the mathematical model of composting process of sewage sludge. Compost Sci. Util. 2016, 24, 73-85. [CrossRef]

97. Seng, B.; Kristanti, R.A.; Hadibarata, T.; Hirayama, K.; Katayama-Hirayama, K.; Kaneko, H. Mathematical model of organic substrate degradation in solid waste windrow composting. Bioproc. Biosyst. Eng. 2016, 39, 81-94. [CrossRef] [PubMed]

98. Wang, Y.; Pang, L.; Liu, X.; Wang, Y.; Zhou, K.; Luo, F. Using thermal balance model to determine optimal reactor volume and insulation material needed in a laboratory-scale composting reactor. Bioresour. Technol. 2016, 206, 164-172. [CrossRef]

99. Külcü, R. New kinetic modelling parameters for composting process. J. Mater. Cycles Waste Manag. 2016, 18, 734-741. [CrossRef]

100. Wang, Y.; Witarsa, F. Application of Contois, Tessier, and first-order kinetics for modeling and simulation of a composting decomposition process. Bioresour. Technol. 2016, 220, 384-393. [CrossRef] [PubMed]

101. Gutiérrez, M.C.; Siles, J.A.; Diz, J.; Chica, A.F.; Martín, M.A. Modelling of composting process of different organic waste at pilot scale: Biodegradability and odor emissions. Waste Manag. 2016, 59, 48-58. [CrossRef]

102. Giusti, E.; Marsili-Libelli, S. Fuzzy modelling of the composting process. Environ. Model Softw. 2010, 25, 641-647. [CrossRef]

103. Alavi, N.; Sarmadi, K.; Goudarzi, G.; Babaei, A.A.; Bakhshoodeh, R.; Paydary, P. Attenuation of tetracyclines during chicken manure and bagasse co-composting: Degradation, kinetics, and artificial neural network modeling. J. Environ. Manag. 2019, 23, 1203-1210. [CrossRef] [PubMed]

104. Roohi, R.; Jafari, M.; Jahantab, E.; Aman, M.S.; Moameri, M.; Zare, S. Application of artificial neural network model for the identification the effect of municipal waste compost and biochar on phytoremediation of contaminated soils. J. Geochem. Explor. 2019, 39, 1058-1068. [CrossRef] 
105. Alavi, N.; Dehvari, M.; Alekhamis, G.; Goudarzi, G.; Neisi, A.; Babaei, A.A. Application of electro-Fenton process for treatment of composting plant leachate: Kinetics, operational parameters and modeling. J. Environ. Health Sci. Eng. 2019, 17, 417-431. [CrossRef]

106. Vidriales-Escobar, G.; Rentería-Tamayo, R.; Alatriste-Mondragón, F.; González-Ortega, O. Mathematical modeling of a composting process in a small-scale tubular bioreactor. Chem. Eng. Res. Des. 2017, 120, 360-371. [CrossRef]

107. Rentería-Tamayo, R.; Vidriales-Escobar, G.; González-Ortega, O.; Alatriste-Mondragón, F. Mathematical modeling of the mesophilic and thermophilic stages of a composting tubular reactor for sewage sludge sanitization. Waste Biomass Valori. 2018, 11, 955-966. [CrossRef]

108. Luangwilai, T.; Sidhu, H.S.; Nelson, M.I. One-dimensional spatial model for self-heating in compost piles: Investigating effects of moisture and air flow. Food Bioprod. Proc. 2018, 108, 18-26. [CrossRef]

109. Martalo, G.; Bianchi, C.; Buonomo, B.; Chiappini, M.; Vespri, V. Mathematical modeling of oxygen control in biocell composting plants. Math. Comp. Simul. 2020, 177, 105-119. [CrossRef]

110. Walling, E.; Vaneeckhaute, C. Novel simple approaches to modeling composting kinetics. J. Environ. Chem. Eng. 2021, 9 , 105243. [CrossRef]

111. Tsiodra, C.; Stathakis, E.; Vlysidis, A.; Vlyssides, A. Development of a dynamic model for the degradation of fats, oils and greases during co-composting of olive mill solid and liquid wastes. Fresenius Environ. Bull. 2018, 27, 4900-4903.

112. Sable, S.; Mandal, D.K.; Ahuja, S.; Bhunia, H. Biodegradation kinetic modeling of oxo-biodegradable polypropylene/polylactide/nanoclay blends and composites under controlled composting conditions. J. Environ. Manag. 2019, 249, 109186. [CrossRef]

113. Sable, S.; Ahuja, S.; Bhunia, H. Biodegradation kinetic modeling of acrylic acid-grafted polypropylene during thermophilic phase of composting. Iran. Polym. J. 2020, 29, 735-747. [CrossRef]

114. Ebrahimzadeh, R.; Ghazanfari Moghaddam, A.; Sarcheshmehpour, M.; Mortezapour, H. A novel kinetic modeling method for the stabilization phase of the composting process for biodegradation of solid wastes. Waste Manag. Res. 2017, 35, 1226-1236. [CrossRef]

115. Samaei, M.R.; Jalili, M.; Abbasi, F.; Mortazavi, S.B.; Jonidi Jafari, A.; Bakhshi, B. Isolation and kinetic modeling of new culture from compost with high capability of degrading n-hexadecane, focused on Ochrobactrum oryzae and Paenibacillus lautus. Soil Sediment Contam. Int. J. 2020, 29, 384-396. [CrossRef]

116. Rafiee, R.; Obersky, L.; Xie, S.; Clarke, W.P. A mass balance model to estimate the rate of composting, methane oxidation and anaerobic digestion in soil covers and shallow waste layers. Waste Manag. 2017, 63, 196-202. [CrossRef] [PubMed]

117. Toledo, M.; Gutiérrez, M.C.; Siles, J.A.; Martín, M.A. Full-scale composting of sewage sludge and market waste: Stability monitoring and odor dispersion modeling. Environ. Res. 2018, 167, 739-750. [CrossRef] [PubMed]

118. Ghinea, C.; Apostol, L.C.; Prisacaru, A.E.; Leahu, A. Development of a model for food waste composting. Environ. Sci. Pollut. Res. Int. 2018, 26, 4056-4069. [CrossRef] [PubMed]

119. Soto-Paz, J.; Oviedo-Ocaña, E.R.; Manyoma, P.C.; Gaviría-Cuevas, J.F.; Marmolejo-Rebellón, L.F.; Torres-Lozada, P.; Sánchez, A.; Komilis, D. A multi-criteria decision analysis of co-substrate selection to improve biowaste composting: A mathematical model applied to Colombia. Environ. Process. 2019, 6, 673-694. [CrossRef]

120. Wang, H.; Bridges, W.; Chen, Z.; Gong, C.; Jiang, X. Comparing and modeling the thermal inactivation of bacteriophages as pathogenic viruses surrogates in chicken litter compost. Compost Sci. Util. 2020, 28, 87-99. [CrossRef]

121. Calisti, R.; Regini, L.; Proietti, P. Compost-recipe: A new calculation model and a novel software tool to make the composting mixture. J. Clean. Prod. 2020, 270, 122427. [CrossRef]

122. Sobieraj, K.; Stegenta-Dabrowska, S.; Koziel, J.A.; Białowiec, A. Modeling of CO accumulation in the headspace of the bioreactor during organic waste composting. Energies 2021, 14, 1367. [CrossRef]

123. Wojcieszak, D.; Zaborowicz, M.; Przybył, J.; Boniecki, P.; Jędruś, A. Assessment of the content of dry matter and dry organic matter in compost with neural modelling methods. Agriculture 2021, 11, 307. [CrossRef] 